\title{
Facts before fiction
}

\author{
Cindy A. Buckmaster, PhD, CMAR, RLATG
}

I have something to tell you. You may find it surprising, but it's true. Animal rights activists are good people. You read it correctly. I'll repeat it: Animal rights activists are good people. They are kind, loving and concerned members of society, like you and me. They love children. They love the elderly. They love animals, and they treasure our bonds with one another. They live to protect those they believe to be vulnerable, and they will stand up for causes that others choose to ignore. They have a passion for compassion, and they believe that love and kindness are worth fighting for, at all costs. Animal rights activists act in love; so does the research community. Our obsession for improving the lives of animals and people through biomedical research is fundamentally grounded in our unconditional love for all creatures. We also have a passion for compassion. We are the same. And we are different. This is why: Activists think they know the truth about what they're fighting for, but they don't. They act in love, based on fiction. Researchers act in love, based on facts. That's the crux of our difference. Otherwise, we're the same. We've just become so lost in the details of our arguments that we have forgotten the truth that joins us; we all love our animals and we all wish they weren't still necessary for biomedical progress. For now, they are. That is a fact. All claims to the contrary are fiction.

We're surrounded by hordes of animal rights activists of one kind or another. Some are homemakers and professionals who donate money to serve causes that speak to them. Some are journalists and television personalities who shape public opinion to serve causes that speak to them. Some are legislators who influence public policies to serve causes that speak to them. Some activists are soft-spoken and persevering. Some are loud and disruptive. And some are angry and dangerous. Regardless of the variety, all of them are puppets for a force of evil they love and trust, like children abused by their parents. They're told what

\section{Activists think they know the truth about what they're fighting for, but they don't. They act in love, based on fiction. Researchers act in love, based on facts.}

to believe, and they believe what they're told. Their emotions have been hijacked and their thoughts controlled. They are soldiers for an agenda that is bound to break their kind hearts - an agenda they would never support if their minds were their own. It's an agenda choreographed and directed by a small number of animal rights extremist organizations, and its aim is to separate people from animals completely and permanently. Why?! I have no idea, but it has nothing to do with any sort of genuine love or concern for animals. Extremist factions prey upon the inherent kindness of masses of ordinary people who truly love animals, because they're easy marks for manipulation. They brainwash them and fuel their fury with lies about the treatment of animals in research and other animal interests, to mobilize armies against the survival of animals and people. Activists are created, not born, and they are fundamentally different from extremists. This is why: Activists love animals and people, but they don't know the truth.
Extremists love power and money, and they don't care about the truth.

People believe the first thing they hear. It's human nature. The research community's silence has allowed fiction to come before facts. People don't know the whole truth, and they're fighting to preserve their illusions, to keep from feeling like illusions themselves. I recently viewed an exposé produced by Glenn Beck for "The Blaze" titled "Socialized Science: The Animal Testing Debate," which featured propaganda from the White Coat Waste Movement (WCWM). The group's spokesman identified the WCWM as "taxpayers' rights activists" and commanded viewers, "Derail the gravy train. When the tax dollars are gone, the animal abusers are gone." The producers billed WCWM as a movement "uniting conservatives and liberals"; it was a sickening carnival of agendas. The episode was rife with disturbing footage from yesteryear, interwoven with blatant mischaracterizations of the work done to benefit human and animal health today. The most inane line in the piece came from a physician of preventative and internal medicine who stated, "As a doctor, I never use data from animal studies to guide my clinical decisions about humans." Seriously?! Virtually everything EVERY doctor knows and shares with his patients was informed by animal-based research! This incontrovertible fact wasn't shared with the audience-extremist cinema at its finest.

Extremists are born evil, but they are outnumbered. Activists are born loving. They are hard-wired to defend compassion for all creatures, and they will never back down. Let's give them facts to defend, before they destroy us all with fiction. 